\title{
Characterization of Bromelain from Parts of Three Different Pineapple Varieties in Nigeria
}

\author{
Omotoyinbo O. V., Sanni D. M.* \\ Department of Biochemistry, Federal University of Technology, Akure, Nigeria
}

Email address:

moraksanni@yahoo.co.uk (Sanni D. M.)

${ }^{*}$ Corresponding author

To cite this article:

Omotoyinbo O. V., Sanni D. M. Characterization of Bromelain from Parts of Three Different Pineapple Varieties in Nigeria. American Journal of BioScience. Vol. 5, No. 3, 2017, pp. 35-41. doi: 10.11648/j.ajbio.20170503.11

Received: December 16, 2016; Accepted: December 29, 2016; Published: April 17, 2017

\begin{abstract}
Bromelain was extracted from crown, flesh, core, and peel of some variant of Nigerian pineapple fruits in order to evaluate its amount and characteristics. Each part of pineapple after separation was weighed, blended, filtered and then filtrate was precipitated with ethanol and centrifuged. All extracts from each stage were collected and assayed for bromelain activity. The concentration of protein was also measured by using BSA as standard while proteolytic activity was determined using Azocasein 1\% (w/v) as substrate at standard conditions. The optimum temperature and $\mathrm{pH}$ were also evaluated. The result showed that bromelain could be obtained from all parts of pineapple. Ananas fitzmulleri (Agric) had the highest weight $(1486.42 \mathrm{~g})$ and flesh content (53.5\%) compared to other varieties while bromelain obtained from all parts and in the different varieties had optimum activity at $40^{\circ} \mathrm{C}$ and $\mathrm{pH}$ of 7 . Hence ethanol precipitation method is viable for bromelain recovery.
\end{abstract}

Keywords: Bromelain, Azocasein, Pineapple Fruits

\section{Introduction}

Bromelain is a collective name for all proteases, sulfhydryl proteolytic enzymes belonging to the Bromeliaceae family [1]; it is one of the protease enzymes found in the pineapple plant (Ananas comosus) [2]. Bromelain is present in all parts of the pineapple plant, but its characteristics depend on the source [3]. The major component, stem bromelain (EC 3.4.22.2), has since been sequenced and shown to be a member of the papain superfamily. The enzyme present in the juice of the pineapple stem is of basic character called stem-bromelain and is the major protease present in extracts of pineapple stem while fruit bromelain (EC 3.4.22.3), the enzyme present in the fruit is an acidic enzyme called fruitbromelain is the major enzyme fraction present in the juice of the pineapple fruit [4]. Muntari et al. [5], reported that bromelain concentration was very high in pineapple stems and hence leading to its extraction and utilization as phytomedicinal compound. Unlike the pineapple fruit which is normally used as food, the stems were waste by-product and thus, very cheap source of bromelain [6]. Also, besides the stem and fruit of pineapple as the source of bromelain it was also discovered that some other part of the pineapple, the core peel and crown has been another source as bromelain was extracted from the peel, core, stem and crown of wastes from two pineapple cultivars [7].

Bromelain has a wide range of therapeutic benefit as property of facilitating digestion of proteins, meat softening, ability to facilitate blood clotting [8], other economic importance are related to the food industry and textiles and production of drugs resulting in an increase of its value [9]. It is proved that Bromelain is well absorbed in body after oral administration and has little or no important side effects even after prolonged use [10]. This study aims at extracting crude bromelain from four different pineapple parts (crown, fruit, flesh and peel of three different local species Ananas fitzmuelleri, Ananas comosus, and Ananas erectifolius, partially purify the bromelain from the four different parts of each species and characterise the bromelain enzyme.

\section{Methodology}

Pineapple fruits of the three different species, locally called the Agric (Ananas fitzmueller), Local (Ananas comosus) and Erec (Ananas erectifolius) were bought from a local market at 
Ilara town on Akure - Ilesha express way, Ondo state. The pineapple fruits were identified by $\mathrm{Mr}$ Hassan at the Department of Crop Science Production of the Federal University of Technology Akure. The pineapple fruits were washed thoroughly with water and then weighed before been peeled and sliced to separate different parts; crown, fruit, flesh and peel and weighed to ascertain percentage part weights.

\subsection{Bromelain Extraction}

Each part was blended with sodium phosphate buffer 0.01 $\mathrm{M} \mathrm{pH} \mathrm{7.0:} \mathrm{flesh} \mathrm{and} \mathrm{core} \mathrm{at} \mathrm{ratio} \mathrm{of} 1: 1(\mathrm{w} / \mathrm{v})$ for the peel, at ratio $2: 1(\mathrm{w} / \mathrm{v})$ while for the crown at ratio of $3: 1(\mathrm{w} / \mathrm{v})$ and filtered using cheese cloth, to obtain the juice. The filtered juice was centrifuged at $6000 \mathrm{~g}$ for 20 minutes at $4^{\circ} \mathrm{C}$. The supernatant obtained (crude bromelain) was collected and refrigerated at $-4^{\circ} \mathrm{C}$.

\subsection{Determination of Enzyme Activity}

The enzyme activity assayed by the azocasein method as described by Oliveira et al. [11], where azocasein $1.0 \%(\mathrm{w} / \mathrm{v})$ (Sigma) was solubilized in $4 \%$ ethanol $(\mathrm{v} / \mathrm{v})$ and $0.1 \mathrm{M}$ phosphate buffer, $\mathrm{pH} 7.0$, and used as substrate. The assay mixture, containing $125 \mu \mathrm{L}$ of substrate and $125 \mu \mathrm{L}$ of extract enzymatic was incubated for $10 \mathrm{~min}$ at $37^{\circ} \mathrm{C}$ and the reaction stopped by addition of $750 \mu \mathrm{L}$ of $5 \%$ trichloroacetic acid $(\mathrm{w} / \mathrm{v})$. The samples were centrifuged at $6000 \mathrm{~g}$ for 10 minutes and at a temperature $4^{\circ} \mathrm{C}$. One unit of activity was defined as the amount of enzyme required to produce the increase in optical density by one unit within 1 hour.

\subsection{Protein Concentration Assay}

Protein content in each bromelain extract was measured by Bradford method [12] using bovine serum albumin (BSA) as standard.

\subsection{Precipitation by Ethanol}

Bromelain precipitation was performed according to methodology described Englard and Seifter [13]. Ethanol $98 \%(\mathrm{w} / \mathrm{w})$ cooled to $0^{\circ} \mathrm{C}$ was added dropwise until concentrations of 30 and $70 \%(\mathrm{w} / \mathrm{w})$ was reached. The solution was then centrifuged at 10,000 for $20 \mathrm{~min}$ at $4{ }^{\circ} \mathrm{C}$ and the resulting pellet was suspended in $20 \mathrm{mM}$ buffer phosphate $\mathrm{pH}$ 7.0.

\subsection{Enzyme Partial Characterization}

Optimum $\mathrm{pH}$ and temperature was evaluated before and after ethanol precipitation. Effect of $\mathrm{pH}$ assays were performed as described during bromelain assay with exchanged buffers so the desired $\mathrm{pH}$ could be reached. Likewise, the effect of temperature was accessed by changing the incubation temperature.

The enzyme preparation used for the assay for the effect of $\mathrm{pH}$ on bromelain activity was stabilized in different buffer of different $\mathrm{pH}$ range, from; Glycine/HCL buffer with $\mathrm{pH} 4$,

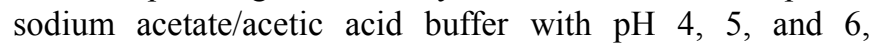
Sodium phosphate buffer with $\mathrm{pH} 7$ and $\mathrm{pH}$ 8. These different buffers were used to prepare the substrate (casein) for the enzyme, while effect of temperature on bromelain activity was evaluated by azo-casein as substrate. Bromelain activity was assayed at temperature between 30 and $70^{\circ} \mathrm{C}$.

\section{Results and Discussion}

From table 1, the weight in gram and their percentage value of the different parts was Ananas fitzmulleri variety had the highest weight in grams followed by Ananas comosus and Ananas erectifolius respectively, with their flesh accounting for the largest percentage for all varieties.

Table 1. Weight of pineapple parts from the three different species.

\begin{tabular}{lllllll}
\hline & Ananas fitzmulleri (Agric) & & Ananas comosus (Local) & & Ananas erectifolius $($ Erec) \\
\hline Parts & Weight $(\mathbf{g})$ & $\mathbf{( \% )}$ & Weight $(\mathbf{g})$ & $\mathbf{( \% )}$ & Weight $(\mathbf{g})$ & $\mathbf{( \% )}$ \\
\hline CROWN & 227.95 & 15.30 & 239.42 & 23.30 & 193.24 & 23.50 \\
CORE & 256.08 & 17.20 & 172.15 & 16.80 & 138.57 & 16.80 \\
FLESH & 794.15 & 53.50 & 474.80 & 46.30 & 395.6 & 48.00 \\
PEEL & 208.24 & 14.00 & 139.56 & 13.60 & 96.82 & 1.70 \\
TOTAL & 1486.42 & 100.0 & 1025.93 & 100.0 & 824.23 & 100.0 \\
\hline
\end{tabular}

Similar report to that obtained in this study was seen by Sobir and Duri [14], who noted that for all the weight in gram and percentage of the different part of the pineapple varieties, the flesh of all the pineapple varieties constitutes the largest weight of the pineapple in gram and percentage.

Table 2. Purification table for Agric pineapple (Ananas fitzmuelleri).

\begin{tabular}{|c|c|c|c|c|c|c|c|}
\hline PARTS & PURIFICATION STEP & Vol. (ml) & $\begin{array}{l}\text { Enz. Activity } \\
(\mathrm{U} / \mathrm{ml})\end{array}$ & $\begin{array}{l}\text { Protein Conc. } \\
(\mu \mathrm{g} / \mathrm{ml})\end{array}$ & $\begin{array}{l}\text { Specific activity } \\
(\mathrm{U} / \mu \mathrm{g})\end{array}$ & yield & Fold \\
\hline \multirow[t]{2}{*}{ AGRIC CROWN } & FIRST CENTRIFUGATN & 200 & 0.0155 & 1.44 & 0.01 & 100 & 1 \\
\hline & 70\% ETHANOL PRECIPITATION & 5 & 0.011 & 1.07 & 0.01 & 100 & 1 \\
\hline \multirow[t]{2}{*}{ AGRIC CORE } & FIRST CENTRIFUGATN & 200 & 0.011 & 1.63 & 0.005 & 100 & 1 \\
\hline & 70\% ETHANOL PRECIPITATION & 5 & 0.06 & 0.67 & 1 & 200 & 0.5 \\
\hline \multirow[t]{2}{*}{ AGRIC FLESH } & FIRST CENTRIFUGATN & 200 & 0.15 & 1.33 & 0.113 & 100 & 1 \\
\hline & 70\% ETHANOL PRECIPITATION & 5 & 0.007 & 0.11 & 0.064 & 56.64 & 1.76 \\
\hline \multirow[t]{2}{*}{ AGRIC PEEL } & FIRST CENTRIFUGATN & 200 & 0.014 & 1.48 & 0.0095 & 100 & 1 \\
\hline & 70\% ETHANOL PRECIPITATION & 5 & 0.01 & 0.74 & 0.0135 & 142.1 & 0.7 \\
\hline
\end{tabular}


Table 3. Purification table for local pineapple (Ananas comosus).

\begin{tabular}{|c|c|c|c|c|c|c|c|}
\hline PARTS & PURIFICATION STEP & Vol. (ml) & $\begin{array}{l}\text { Enzyme } \\
\text { activity. (U/ml) }\end{array}$ & $\begin{array}{l}\text { Protein conc. } \\
(\mu \mathrm{g} / \mathrm{ml})\end{array}$ & $\begin{array}{l}\text { Specific activity } \\
(\mathrm{U} / \mu \mathrm{g})\end{array}$ & Yield & Fold \\
\hline \multirow[t]{2}{*}{ LOCAL CROWN } & FIRST CENTRIFUGATN & 200 & 0.0068 & 1.29 & 0.0053 & 100 & 1 \\
\hline & 70\% ETHANOL PRECIPITATION & 5 & 0.014 & 0.85 & 0.0165 & 311.32 & 0.32 \\
\hline \multirow[t]{2}{*}{ LOCAL CORE } & FIRST CENTRIFUGATN & 200 & 0.011 & 0.96 & 0.0115 & 100 & 1 \\
\hline & 70\% ETHANOL PRECIPITATION & 5 & 0.013 & 0.62 & 0.02 & 173.91 & 0.58 \\
\hline \multirow[t]{2}{*}{ LOCAL FLESH } & FIRST CENTRIFUGATN & 200 & 0.0068 & 1.11 & 0.006 & 100 & 1 \\
\hline & 70\% ETHANOL PRECIPITATION & 5 & 0.006 & 0.41 & 0.015 & 250 & 0.4 \\
\hline LOCAL PEEL & 70\% ETHANOL PRECIPITATION & 5 & 0.01 & 0.67 & 0.015 & 100 & 1 \\
\hline
\end{tabular}

Table 4. Purification table for Erec (Ananas erectifolius).

\begin{tabular}{|c|c|c|c|c|c|c|c|}
\hline PARTS & PURIFICATION STEP & Vol. (ml) & $\begin{array}{l}\text { Enzyme } \\
\text { activity. }(\mathrm{U} / \mathrm{ml})\end{array}$ & $\begin{array}{l}\text { Protein conc. } \\
(\mu \mathrm{g} / \mathrm{ml})\end{array}$ & $\begin{array}{l}\text { Specific } \\
\text { activity }(U / \mu g)\end{array}$ & Yield & Fold \\
\hline \multirow[t]{2}{*}{ EREC CROWN } & FIRST CENTRIFUGATN & 190 & 0.0038 & 1 & 0.0038 & 100 & 1 \\
\hline & 70\% ETHANOL PRECIPITATION & 5 & 0.0087 & 0.85 & 0.01 & 263.2 & 0.38 \\
\hline \multirow[t]{2}{*}{ EREC CORE } & FIRST CENTRIFUGATN & 190 & 0.007 & 1.18 & 0.0011 & 100 & 1 \\
\hline & 70\% ETHANOL PRECIPITATION & 5 & 0.0085 & 1.37 & 0.0063 & 572.73 & 0.18 \\
\hline \multirow[t]{2}{*}{ EREC FLESH } & FIRST PRECIPITATION & 190 & 0.0014 & 1.18 & 0.012 & 100 & 1 \\
\hline & 70\% ETHANOL PRECIPITATION & 5 & 0.009 & 1.15 & 0.008 & 66.67 & 1.45 \\
\hline EREC PEEL & $70 \%$ ETHANOL PRECIPITATION & 5 & 0.006 & 0.59 & 0.01 & 102.04 & 0.98 \\
\hline
\end{tabular}

Tables 2, 3 and 4 shows the level of purification fold obtained with results of the enzyme activity, the protein concentration and the specific activity of the bromelain extracted after first centrifugation and $30-70 \%$ ethanol precipitation, for the three variety of pineapple considered in this study. The purification factor for the first centrifugation and the $70 \%$ ethanol precipitation showed a decrease in the total enzyme activity and the total protein concentration after $70 \%$ ethanol precipitation of bromelain for all part of the Ananas fitzmulleri, except for its core, whose total enzyme activity for $70 \%$ ethanol precipitation $(3.35 \mathrm{U} / \mathrm{ml})$, was higher than its first centrifugation $(2.20 \mathrm{U} / \mathrm{ml})$. Also the specific activity, yield and fold of the Ananas fitzmulleri parts increases after $70 \%$ ethanol concentration. Rabelo et al. [15], reported similar increase for the pineapple variety he studied. except for its flesh where the specific activity and yield decreases while the fold increases.

Similarly findings was observed for Ananas comosus, with the total enzyme activity and total protein concentration decreasing after $70 \%$ ethanol precipitation, while specific activity and yield increases at this level of purification for all parts of Ananas comosus. However, bromelain recovery fold at the precipitation level decreases for all parts considered except for the peel where the bromelain fold at the first centrifugation level and $70 \%$ ethanol precipitation level were the same. The total enzyme activity and total protein concentration decreases at precipitation level for all parts of Ananas erectifolius, its specific activity and yield increases and fold decreases for all its parts at precipitation level except for the fleshy part whose specific activity (0.008) and yield (66.67) decreases and the fold (1.45) increases at the $70 \%$ ethanol precipitation level of purification.

Figure 1, 2 and 3 shows the effect of temperature on the activity of bromelain for all varieties of the pineapple. A gradual increase was observed within the range of $30-35^{\circ} \mathrm{C}$ while a peak was obtained at temperature of $40^{\circ} \mathrm{C}$.

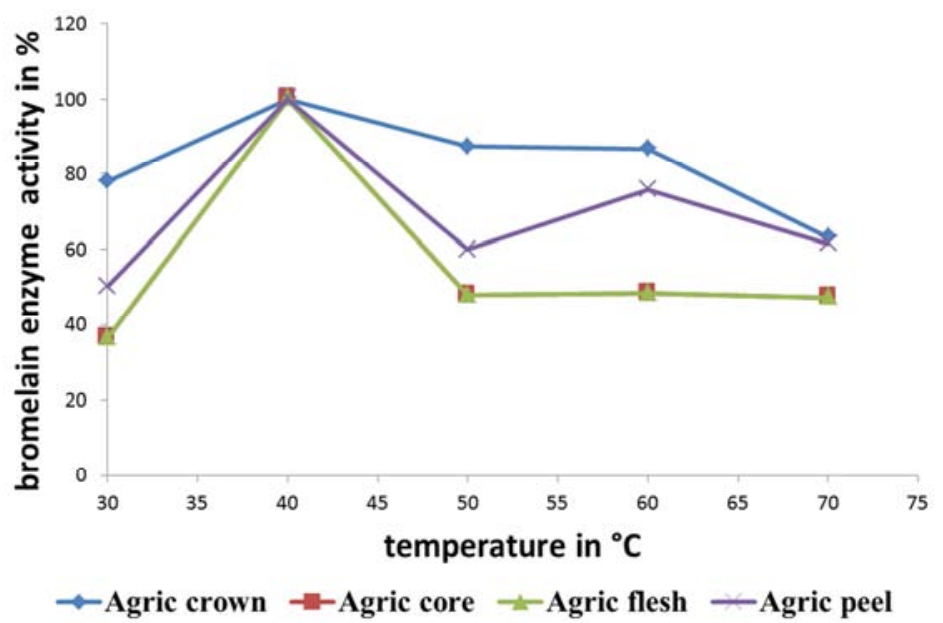

Figure 1. Effect of temperature on bromelain activity obtained from Agric pineapple (Ananas fitzmuelleri). 


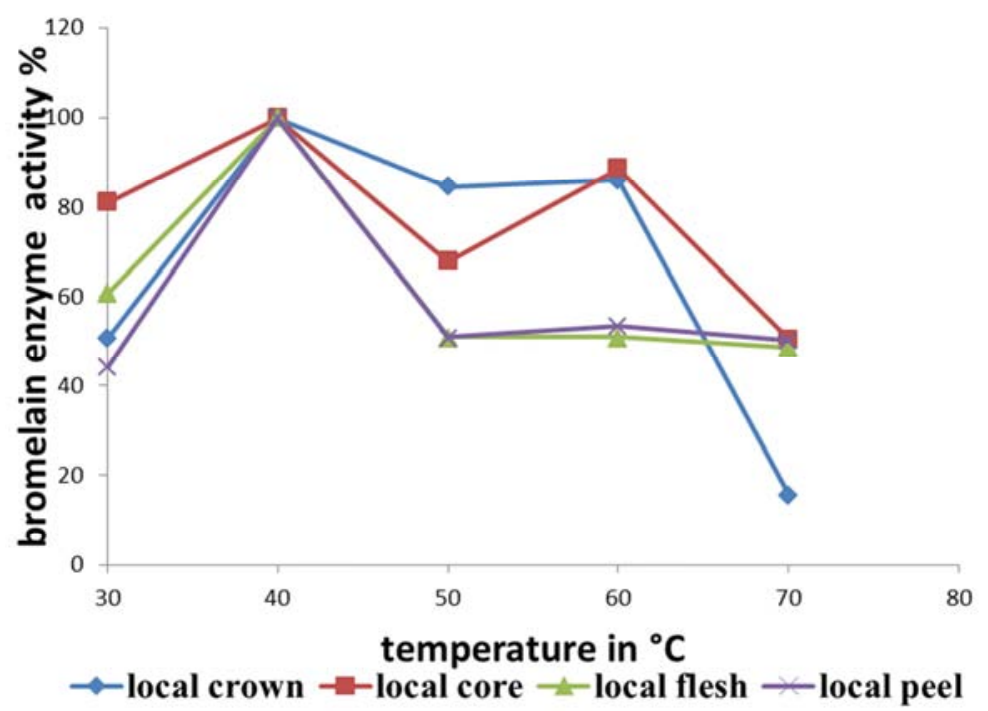

Figure 2. Effect of temperature on bromelain activity obtained from Local pineapple (Ananas comosus).

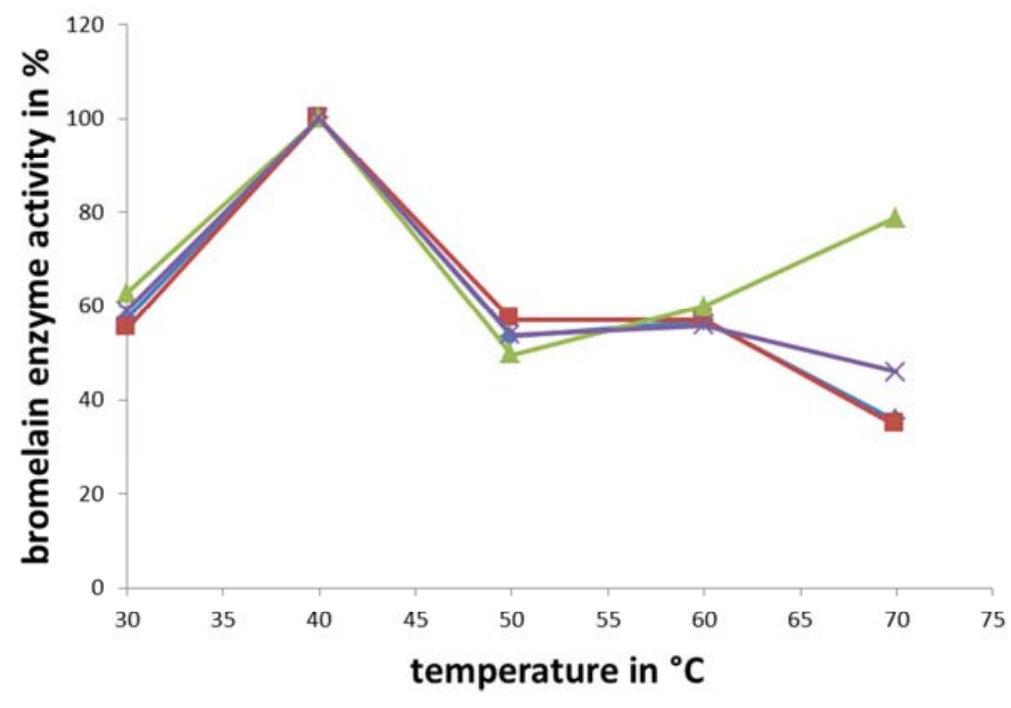

\section{$\multimap$ eric crown $\rightarrow$-eric core $\leftarrow$ eric flesh $\multimap$ eric peel}

Figure 3. Effect of temperature on bromelain activity obtained from Erec pineapple (Ananas erectifolius).

The optimum temperature observed for bromelain activity in all parts of pineapple varieties considered (Ananas fitzmulleri, Ananas comosus and Ananas erectifolius), was $40^{\circ} \mathrm{C}$. This result corresponds and was also supported by the work of Harrach et al., [16] who reported the optimum temperature of the bromelain activity at $40-65^{\circ} \mathrm{C}$ for stem bromelain, Amid et al. [17] used a purified recombinant bromelain and this exhibited the highest hydrolytic activity at $45^{\circ} \mathrm{C}$ under routine assay conditions, however, the enzyme was devoid of detectable activity at $65^{\circ} \mathrm{C}$. Ferreira et al., [18] noted that the ideal temperature range for the characterization of bromelain from pineapple stem bark is between $30^{\circ} \mathrm{C}$ and $40^{\circ} \mathrm{C}$, which supports the similar behaviour observed in this study between bromelain from the different pineapple varieties. These results are also comparable to the characteristics of pineaple bromelain, which is active between $40^{\circ} \mathrm{C}$ and $60^{\circ} \mathrm{C}$ [19]. Furthermore bromelain activity was observed to be stable with approximately $50 \%$ enzyme activity at temperature range of $30-60^{\circ} \mathrm{C}$ until it finally began to reduce in activity at $70^{\circ} \mathrm{C}$. This was observed for all parts of Ananas comosus and Ananas fitzmulleri except for the fleshy part of Ananas erectifolius where bromelain activity was seen to increase in activity at $70^{\circ} \mathrm{C}$. Similar result was reported for fruit bromelain which had its maximum activity at $70^{\circ} \mathrm{C}[20]$, also, bromelain from other pineapple, such as Perola variety from Brazil, had their maximum activity also at $70^{\circ} \mathrm{C}$ [21]. Temperature is a critical agent on the enzyme activity. When the temperature rises, the activity initially increases, however the process thereafter declines due to the denaturing action of heat [22].

The effect of $\mathrm{pH}$ on the activity of bromelain is shown in Figure 4, 5 and 6 . The optimum activity was observed at $\mathrm{pH}$ 7.0. The enzyme was more active in the $\mathrm{pH}$ of 4,6 , and 7 . There was a gradual decline in the activity of the enzyme after attaining the optimum $\mathrm{pH}$ of 7.0. 


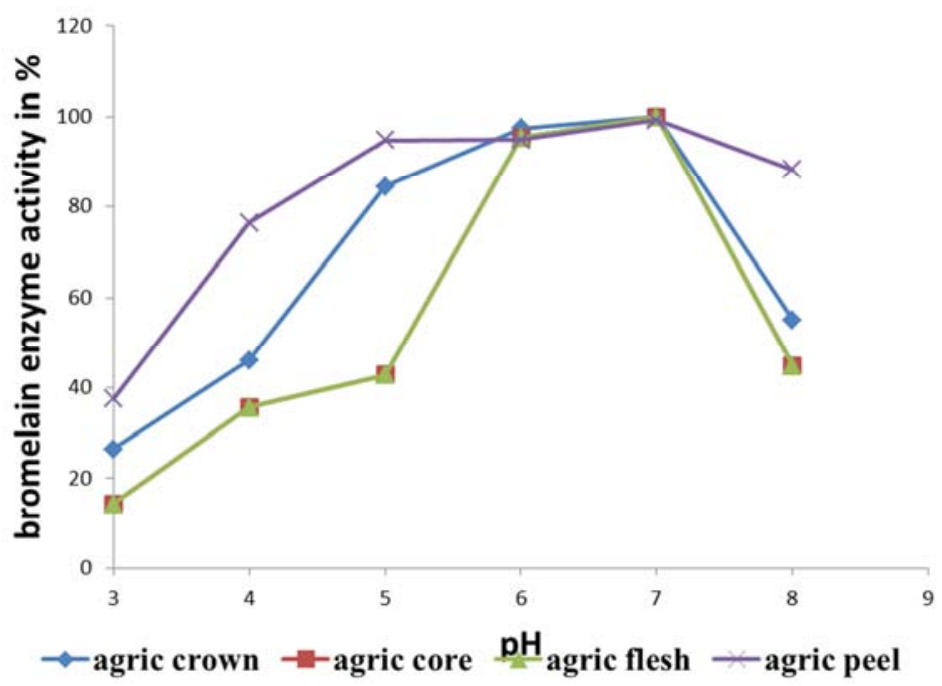

Figure 4. Effect of bromelain on bromelain activity obtained from Agric pineapple (Ananas fitzmuelleri).

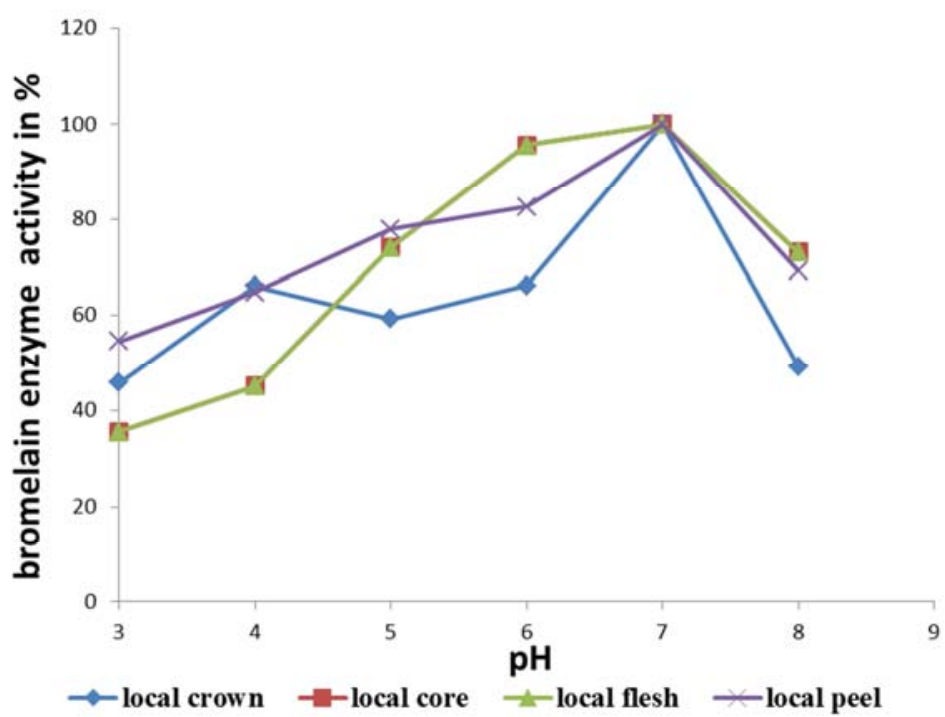

Figure 5. Effect of bromelain on bromelain activity obtained from Local pineapple (Ananas comosus).

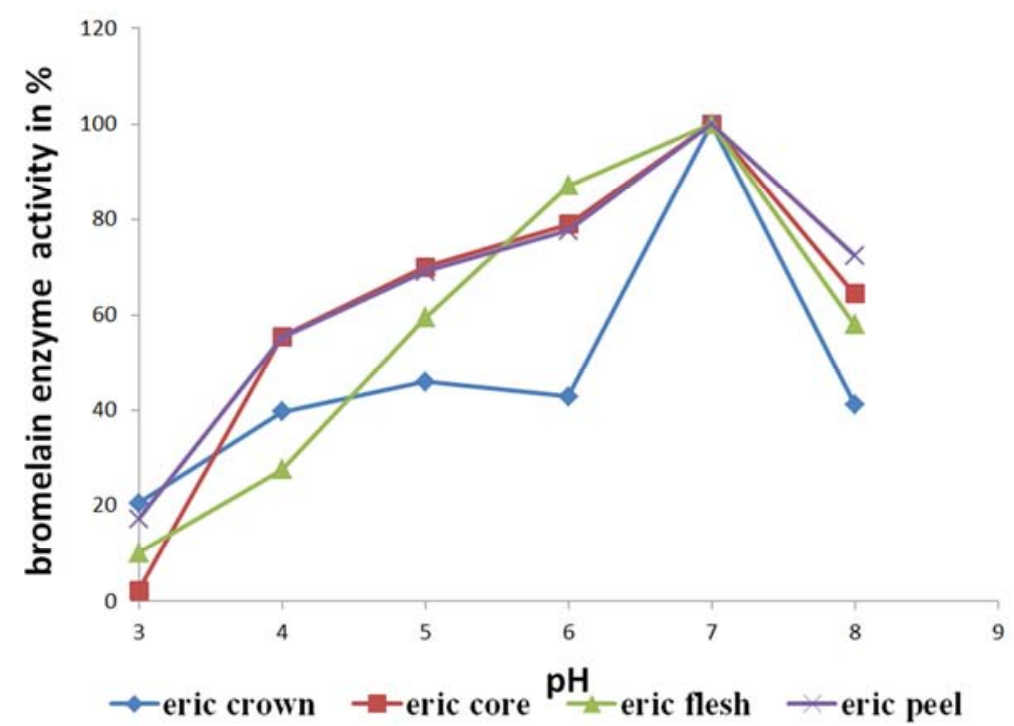

Figure 6. Effect of bromelain on bromelain activity obtained from Erec pineapple (Ananas erectifolius). 
Optimal $\mathrm{pH}$ for bromelain activity was at $\mathrm{pH} 7.0$ for all parts of the pineapple varieties considered in this study. This result corresponds to bromelain activity as reported by Martowibowo et al., [23]. Bromelian active at $\mathrm{pH} 3$ through to $\mathrm{pH} 7$ where it activity is at maximal until it finaly falls at pH 8 for all parts of the pineapple. Corzo et al., [24] and Manzoor et al., [25] support the result as it was reported that bromelain act well within $\mathrm{pH}$ range $3-8$. Beyond this $\mathrm{pH}$ value, the activity declined progressively. The effect of $\mathrm{pH}$ can be explained considering the surface charge on the adsorbent material. At low $\mathrm{pH}$, due to the high positive charge density, electrostatic repulsion will be high, resulting in lower uptake of positively charged bromelain. The isoelectric point of bromelain is 9.55 [26], hence the adsorption decreases at a higher $\mathrm{pH}$. Some proteins contain acid labile groups and even relatively mild acid treatment may cause irreversible loss of function. The optimum $\mathrm{pH}$ of bromelain from pineapple fruits was reported to be 7.0. Enzymes are generally sensitive to $\mathrm{pH}$ changes in their environment and have optimum $\mathrm{pH} 7.0$ at which they have their maximum activity, beyond which their activity decreases [27].

\section{Conclusion}

Crude bromelain extracted and partially purified by ethanol precipitation from pineapple parts of three different varieties (Ananas fitzmuelleri, Ananas comosus, and Anana erectifolius) showed considerable physiochemical properties, with activity at temperature range of $30-70^{\circ} \mathrm{C}$ and $\mathrm{pH}$ range of $5-8$. This precipitation method shows that bromelain recovery process is a viable process in which results in a good quality enzyme which can be considered for industrial purposes.

\section{References}

[1] Souza, O. P., Coutinho, A. C., Torres, T. L. R. (2010). Avaliação econômica da produção doacabaxi irrigado cv Smooth Cayenne no Cerrado, em Uberaba-MG. Revista Universo Rural, 30 (1): 00-00.

[2] Kelly, G. S. (1996). Bromelain: A literature review and discussion of its therapeutic applications. Altern. Med. Rev., 1: 243-257.

[3] Bhattacharyya, B. K. (2008). Bromelain: an overview. Natural Product Radiance, 7: 359-363.

[4] IUB Enzyme Nomenclature Committee (1984). Enzyme Nomenclature, pp.352, Academic Press, New York.

[5] Muntari, B., Nurul, A. I., Maizirwan, M., Mohamed, S. J., Hamzah, M. S., Azura, A. (2012). Bromelain Production: Current Trends and Perspective. Archives Des Sciences, 65 (11): 1-31

[6] Tochi, B. N., Wang, Z., Xu, S. Y., Zhang, W. (2008). Therapeutic application of pineapple protease (bromelain). Pakistan Journal of Nutrition, 7: 513-520.
[7] Ketnawa, S., Chaiwut, P., Rawdkuen, S. (2012). Pineapple wastes: A potential source for bromelain extraction. Food Bioprod. Process., 90: 385-391.

[8] Abílio, G. M. F., Holschuh, H. J., Bora, P. S., Oliveira, E. F. (2009). Extração, atividade da bromelina eanálise de alguns parâmetros químicos em cultivares de abacaxi. Rev. Bras. Frutic., 31: 1117-1121.

[9] Coelho, D., Barbosa, S. A., Silveira, E., Souza, R. R., Tambourgi, E. (2012). Biosurfactant Production from Unconventional Resources: a Short Overview. International Review of Chemical Engineering, 4 (2): 175183.

[10] Pavan, R., Jain, S., Kumar, A. (2012). Properties and therapeutic application of bromelain: a review. Biotechnology research international, 2012. pina Ananas comosus (L.) Merrill. Revista de la Facultad de Agronomia (Maracay), 16: $1-11$.

[11] Oliveira, L. A., Porto, A. L. F., Tambourgi, E. B. (2006). Production of xylanase and protease by Penicillium janthinellum CRC 87M-115 from different agricultural wastes, Bioresource Technology. 97: 862-867.

[12] Bradford, M. M. (1976). A rapid and sensitive method for the quantitation of microgram quantities of protein utilizing the principle of protein-dye binding, Analytical Biochemistry. 72: 248-254

[13] Englard, S., Seifter, S. (1990). Precipitation techniques in: Guide to protein purification, Eds. Deutscher, M. P., Academic Press, San Diego, USA.

[14] Sobir, Duri, T. (2008). Karakterisasi sifat fisik dan kimia serta perubahannya selama penyimpanan empat cultivar nenas. Enviagro J Pertanian Lingkungan 2 (1): 1-40.

[15] Rabelo, A. P. B., Tambourgi, E. B. and Pessoa, A. (2004). Bromelain partitioning in two-phase aqueous systems containing PEO-PPO-PEO block copolymers, $J$. of Chromatography B. 807, 61-68.

[16] Harrach, T., Eckert, K., Maurer, H. R., Machleidt, I. W., Nuck, R. (1998). Isolation and characterization of two forms of an acidic bromelain stem proteinase. J. Protein Chem., 17 (4): 351-61.

[17] Amid, A., Ismail, N. A., Yusof, F., Salleh, H. M. (2011). Expression, purification, and characterisation of a recombinant stem bromelain from Ananas comosus. Process Biochem. 46 (12): 2232-2239.

[18] Ferreira, J. F., Bresolin, I. R. P., Silveira, E., Tambourgi, E. (2011). Purification of Bromelain from Ananas comosus by PEG/Phosphate ATPS. Chem. Eng. Trans., 24: 931-936.

[19] Okino, N., Ikeda, R., Ito, M. (2010). Expression, purification, and characterization of a recombinant neutral ceramidase from Mycobacterium tuberculosis. Biosci. Biotechnol. Biochem., 4: 316-321.

[20] Suh, H. J. Lee, H. Cho, H. Y., Yang, H. C. (1992). Purification and characterization of bromelain isolated from pineapple. $J$. Korean Agric Chem Soc, 35 (4): 300-307.

[21] Silvestre, M. P. C. Carreira, R. L. Silva, M. R. Corgosinho, F. C. Monteiro, M. R. P., Morais, H. A. (2012). Effect of pH and temperature on the activity of enzymatic extracts from pineapple peel. Food Bioprocess Technol, 5: 1824-1831. 
[22] Halpern, V. (1997). The significance of temperaturedependent distributions of activation energies. J. Physics: Condensed matter, 9: 25

[23] Martowibowo, H., Romasi, E. F., Thenawidjaja, M. (2009). Extraction and characterization of bromelain from pineapple's crown. International Conference and Exhibition-Science and Technology in Biomass Production: Optimizing UniversityIndustry Collaboration West Hall and East Hall ITB, 25-26.

[24] Corzo, C. A., Krzysztof, Waliszewski, K. N., Welti-Chanes, J. (2011). Pineapple fruit bromelain affinity to different protein substrates. Food Chemistry, 133 (3): 631-635.

[25] Manzoor, Z., Nawaz, A., Mukhtar, H., Haq, I. (2016). Bromelain: Methods of Extraction, Purification and Therapeutic Applications. Braz. arch. biol. technol. 59: doi.org/10.1590/1678-4324-2016150010
[26] Wharton, C. W., Cornish-Bowden, A., Brocklehurst, K., Crook, E. M. (1974). Kinetics of the hydrolysis of N-benzoylL-serine methyl ester catalysed by bromelain and by papain. Analysis of modifier mechanisms by lattice nomography, computational methods of parameter evaluation for substrateactivated catalyses and consequences of postulated nonproductive binding in bromelain- and papain-catalysed hydrolyses. Biochem J. 141 (2): 365-381.

[27] Afiukwa, F. N., Iroha, I. R., Afiukwa, C. A., Ayogu, T. E., Oji, A. E., Onwa, N. C. (2010). Presence of coliform producing extended spectrum beta lactamase in sachet-water manufactured and sold in Abakaliki, Ebonyi State, Nigeria. Int. Res. J. Microb. 1 (2): 32-36. 